\title{
Corporate Social Responsibility: Adoption of Green Marketing by Hotel Industry
}

\author{
S. Punitha ${ }^{1} \&$ Roziah Mohd Rasdi ${ }^{2}$ \\ ${ }^{1}$ Department of Management and Marketing, Faculty of Economics and Management, Universiti Putra Malaysia, \\ Serdang, Selangor, Malaysia \\ ${ }^{2}$ Department of Professional Development and Continuing Education, Faculty of Educational Studies, Universiti \\ Putra Malaysia, Serdang, Selangor, Malaysia \\ Correspondence: Roziah Mohd Rasdi, Department of Professional Development and Continuing Education, \\ Faculty of Educational Studies, Universiti Putra Malaysia, 43400 Serdang, Selangor Darul Ehsan, Malaysia. \\ E-mail: roziah_m@upm.edu.my
}

Received: May 31, 2013 Accepted: September 6, 2013 Online Published: November 29, 2013

doi:10.5539/ass.v9n17p79 URL: http://dx.doi.org/10.5539/ass.v9n17p79

\begin{abstract}
This study which is based on a widespread review of literature discusses about adoption of green marketing by hotels as a mechanism to perform corporate social responsibility (CSR). This paper examines in detail the literature and theories surrounding CSR, Malaysian government's role in protecting the environment, the challenges of green marketing and the state of CSR within the hotel industry. The discussion reveals that hotels are found to be under constant pressure to balance the diverse forms of corporate social responsibility. By knowing the significance of sustainability, the Malaysian government has been encouraging the hotels and other sectors to embrace green technology and practices by providing incentives and tax breaks. Whilst hoteliers are striving to achieve financial performance by practicing green marketing, gaining the trust and meeting the expectations of the public have become more challenging. Further review discloses that strategy such as greenwashing needs to be avoided by hoteliers to gain the confidence among green consumers towards the green claims. The paper further concludes that green marketing is being used as a tool by hotels to perform their CSR while it provides competitive advantage for hotels in ensuring a balance between development and environmental sustainability.
\end{abstract}

Keywords: corporate social responsibility (CSR), green marketing, hotel industry, tourism, environment, hospitality management

\section{Introduction}

Due to a recent growth in environmental concerns among the communities over the last few decades, the demand for sustainable development and green marketing has been achieving its momentum greatly (Chen \& Chang, 2012; Jhawar et al., 2012; Leonidou, Leonidou, Fotiadis \& Zeriti, 2013). The ultimate goal of sustainability is depicted as a development that includes formulating a social and economic system which must be incorporated within environmental concerns (Griffin \& Prakash, 2010; Saadatian, Lim, Mat \& Sopian, 2012). This has placed a high pressure on corporations to carry their social and environmental obligations and revise their business operations and practices accordingly to develop sustainable business processes (Smerecnik \& Andersen, 2011) to survive in the long run (Lundberg, Fredman \& Wall-Reinius, 2012). In this manner, the concept of green marketing has emerged together and has become an important buzz-phrase in core operations of many businesses all around the world. The emergence of this term has provided comfort to many companies to use this as a mechanism to perform corporate social responsibility (CSR) (Shafaat \& Sultan, 2012).

Focusing on the service industry, tourism with its amazing development in recent years, has been contributing to so much effects to the nature and the ecology (Graci \& Dodds, 2008; Rodríguez \& Cruz, 2007). Indistinguishably associated with the tourism is the hotel industry which consumes a vast amount of energy, water and non-durable products also provides huge damages to the environment more than the other categories of services of comparable size (Bohdanowicz, 2006; Hsieh, 2012; Leonidou et al., 2013; Nicholls \& Kang, 2012; Robinot \& Giannelloni, 2010). Being a country that is blessed with lush rainforests and splendid species of wildlife, the United Nations World Tourism Organisation (UNWTO) has ranked Malaysia as the ninth most 
travelled destination point in the world (Ministry of Tourism Malaysia, 2012).

Since tourism has become a significant source of income for the country, its contribution to the hotel industry is extremely huge (Leonidou et al., 2013). According to a research done by Klee (as cited in Zainordin, Abdullah \& Baharum, 2012), buildings are consuming about one-third of the world's energy and the consumption of worldwide energy is estimated to increase by $45 \%$ from year 2002 to 2025 . Also stated, $90 \%$ of the energy used in Malaysia is in the form of electricity and it is projected that buildings will consume nearly as much as industry and transport combined if this trend continues. Besides all the other types of buildings such as residential, shopping complexes and offices, hotels are also one of them. Referring to the Tenth Malaysia Plan of 2011-2015 by the Economic Planning Unit (as cited in Hemdi, Razali, Rashid \& Nordin, 2012), the total supply of hotel rooms has increased from 165,739 rooms in year 2008 to 168,497 rooms in year 2010 due to the steady growth of tourism industry. It is also expected to grow further due to the increase in the number of tourist arrivals every year (Hamid, Ismail, Fuza, Ahmad \& Awang, 2012) and its contribution towards the environment is high. Besides energy consumption, extreme levels of water usage and non-durable products offered by hotels can also affect the environment.

Thus, knowing how the hoteliers are contributing to the environment is very much important. According to Myung, McClaren and Li (2012), the present condition of environmentally related researches is relatively young but emerging with high requirements for more academic research in the field of hospitality management. Also mentioned, the concept of green marketing in the area of hotel industry is still in its infancy stage while further literature developments and theoretical supports are required. In addition, studies on the level to which hoteliers make available of their CSR initiatives to the community are still lacking (Holcomb, Upchurch \& Okumus, 2007).

The objective of this paper is to focus on the roles that the hoteliers can perform in the preservation of the natural environment by incorporating various green practices into their operations. A latent objective is to highlight how green marketing is seen within CSR in the hotel industry as a way to protect the environment. This study will be beneficial mainly to the hoteliers as the discussion provides some insights about the importance and ways to perform green practices in their daily operations which could also serve as a tool to implement their CSR initiatives. Besides that, knowing the challenges of this concept will also help them in strategizing their marketing tactics to target the green market. As this paper also discusses the challenges and various environmental protection policies enacted by the Malaysian government, it helps the hoteliers to understand their roles and duties as corporate citizens and the necessity to comply with the laws. Further, it also alerts the reader that the Malaysian policies have certain substantial elements which are in line with all other industrializing countries and may deliver richer and more reliable input to policy formulation.

This paper first offers the definitions of CSR, the literature surrounding CSR and then discusses the Malaysian government's role in protecting the environment. Later, the definition and the challenges of green marketing in relation to the hotel industry are described. Finally, the state of CSR within the hotel industry and its contribution to the community are further explained. The final section derives the study's recommendation, conclusion and suggests future research directions. This study is based on a widespread review of related literature published online. The papers reviewed were not only from Malaysia but include studies done in other countries around the world. The related studies were identified by using keywords such as "corporate social responsibility", "green marketing", "hospitality", "hotel industry", "sustainable development" and "environment". The papers were obtained from the university's subscribed free databases such as Taylor \& Francis, Emerald, Science Direct, EBSCOHost, SAGE Journals Online and Blackwell Synergy.

\section{Literature Review}

\subsection{Corporate Social Responsibility (CSR) and Its Theories}

Corporate social responsibility (CSR) is in a "pre-paradigmatic phase where there is scant agreement on definitions and terms and no consensus has been reached about what it includes and does not include in its boundaries" (Googins, Mirvis \& Rochlin, 2007, p. 29). In fact, the meaning of this concept has been evolving in definition and practice (Baron, 2001; Carroll \& Shabana, 2010; Lee, 2008; Secchi, 2007). Dahlsrud (2008) has identified that there are 37 definitions for CSR. According to Ismail (2009), other terms that can be referred to CSR are corporate social opportunity, corporate responsibility, responsible business and corporate citizenship. Given that the term CSR itself contains the feature of "society" within its own label, this provides a clear understanding that CSR relates to "social" responsibilities of businesses all along (Brammer, Jackson \& Matten, 2012).

Carroll (1979, p. 500) has stated that CSR is "the social responsibility of business encompasses the economic, 
legal, ethical and discretionary expectations that society has of organisations at a given point in time". Later, he has designed "The Pyramid of Corporate Social Responsibility" which includes all four components in which discretionary also later referred to philanthropic in his study (Carroll, 1991, 1999). This pyramid has been used widely and it is one of the most recognized and most cited within the CSR literature. However, the order of the CSR layers proposed by Carroll (1991) actually reveals how it is manifested in developed nations. Visser (2008) has contended that the relative emphasis assigned to each component is different for developing countries such as Malaysia in which economic responsibilities still get the highest priority, followed by philanthropy, then legal and finally ethical responsibilities.

The economic component explains that businesses are responsible to provide a return on investment to owners and shareholders. At the same time, they provide jobs to the society and produce goods and services and selling them for profit (Visser, 2008). It also serves as a competitive advantage (Mahmood \& Humphrey, 2013) as they find efficient ways to operate the business and innovate their offerings to increase the business's revenue (Alniacik, Alniacik \& Gene, 2011; Carroll, 1991). The utilitarian theories have also defined the organisations as a part of the economic system while their main focus is generally on profit maximization (Secchi, 2007). Ismail $(2009$, p. 201) has also mentioned that "CSR ideas emerged after a realization that there is a need for an economic responsibility".

The second component is philanthropic which is merely discussing about promoting the welfare of humans and spreading goodwill by engaging in humanitarian or voluntary programs (Carroll, 1991). According to Cowper-Smith and de Grosbois (2011), one of the ways that organisations make their CSR initiatives known to the public is through voluntary communications. Developed nations see philanthropic responsibility as compulsory via the legal settings but it is an expected norm for developing countries (Visser, 2008). At the same time, CSR activities seemed to be very important especially for MNCs as they have greater visibility and commonly face high media exposure with greater involvement of the community (Fougère \& Solitander, 2009; Sotorrío \& Sánchez, 2010). Schmidheiny (2006) has also strengthened that social issues are always given high media publicity in developing countries. Based on instrumental theory, it has been reasoned that social activities are actually recognized as instruments for marketing to achieve economic objectives (Ismail, 2009). By engaging in voluntary programs, the organisation will be seen as a corporate that is socially responsible which meets the expectations of the community and be the preferred ones (Jamali \& Mirshak, 2007; Wood, 2010).

The legal component suggests that companies must ensure that their business practices are legal and they are performing in a manner that is consistent with the rules and regulations set by the government and other related bodies for the benefit of the society (Carroll, 1991; Ismail, 2009; Mullerat \& Brennan, 2005). The government itself plays an important role in attending and sustaining the public's interests (Detomasi, 2008; Sundaram \& Inkpen, 2004) via legislation and regulation resulted from the consultation with the public (Colley, Doyle, Logan \& Stettinius, 2003). According to Shum and Yam (2011), established laws could also act as tools to inform the stakeholders about the right behaviours without any compromises. Legal responsibility also comprises environmental regulations in which these regulations form a huge contribution towards the overall legislation of a country. To evade adverse legal consequences such as unnecessary fines and even imprisonment, organisations ensure that their operations are parallel to the environmental standards set by the government (Smith \& Perks, 2012). Not wanting to breach such laws, this indirectly gives pressure to the managers to undertake CSR initiatives. Similarly, laws regarding sales, advertising, product safety, labelling and labour have also been officialised to safeguard both producers and consumers (Larsen \& Lawson, 2012). Another benefit of established law and regulations is to ensure that all economic agents are protected while the organisation's self-interest is kept at optimum level (Shum \& Yam, 2011).

The last component is ethical which is known as a component beyond the stated law. A company's ethical responsibilities could include strategies to sustain the environment for future generations, civil rights and adopting moral norms or values that are recognized by the society (Carroll, 1991). Hiseh (2009) and Tsoi (2010) have also stated that as businesses are making profits from the public, they need to act ethically and comprehend the welfare of the society. Thus, this becomes a competitive advantage (Mahmood \& Humphrey, 2013) for them to further progress by creating a positive image among the society and gain more profit (Bondy, Moon \& Matten, 2012).

However, it should be noted that even though the four components have been discussed as separate constructs, they are not mutually exclusive but are interrelated to one and another while they are seen as a unified system (Carroll, 1991; Carroll \& Shabana, 2010; Okpara \& Wynn, 2012). Managers are also found to be under constant pressure to balance these forms of responsibilities (Shum \& Yam, 2011). Figure 1 shows the CSR pyramid for developing countries as proposed by Visser (2008). 


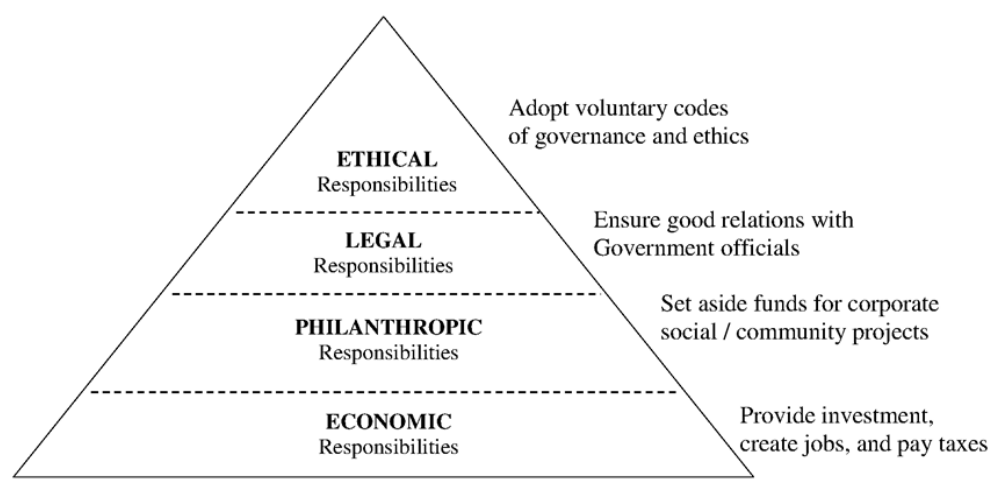

Figure 1. CSR pyramid for developing countries

Adapted from Visser (2008), p. 489

\subsection{Malaysian Government and Its CSR}

Driven by industrial advancement, Malaysia is known to be one of the fast developing countries in the ASEAN province (Ali, 2011). These extreme industrialization, vibrant development growth and vigorous consumption patterns have been adversely affecting the quality of the environment and its future. To cater this problem, the Malaysian government has introduced important regulations to protect the community by minimizing the effect of businesses on the environment ( $\mathrm{Lu} \&$ Castka, 2009). Also known, Malaysia is one of the earliest countries in the world that has given serious attention to the issues related to the environment by enacting the Environmental Quality Act in year 1974 (Sinnappan \& Rahman, 2011). Recently, sustainability is known as one of the three goals highlighted in the New Economic Model of Malaysia. The Prime Minister of Malaysia, Dato' Sri Mohd Najib Tun Razak has mentioned that "the New Economic Model must include a commitment to sustainability, not only in our economic activities, but in considering the impact of economic development on our environment and precious natural resources. There is little value in pursuing a future entirely based on wealth creation. Pursuing growth that depletes resources and displaces communities will have dire consequences for future generations" (Bursa Malaysia Berhad, 2010, p. 1).

Singh and Pandey (2012) have reported that the awareness of green marketing among corporations was mainly due to the pressure and legislations set by the Malaysian government. According to Jamali (2008) and Bondy et al. (2012), the government is also seen as one of the stakeholders and to a great extent, it is required to perform its CSR for the benefit of the society. Knowing that governance reform grasps the main key to advancements of all extents, embracing more ethical governance practices would become the basis for CSR practice in developing countries which would require for more prevalent responsible businesses (Visser, 2008). Referring to political theories conceptualized by Garriga and Melé (2004) and supported by Detomasi (2008), the social responsibilities of an organisation developed based on the amount of social and political power it has while the organisation is also known as one of the citizens which requires a certain contribution to the community.

Ministry of Energy, Green Technology and Water or also known as Kementerian Tenaga, Teknologi Hijau dan Air (KeTTHA) was formed in year 2009 by the government. KeTTHA's roles are to manage and administer the nation's energy, green technology and water utilities. The ministry has also enacted the National Green Technology Policy (NGTP) right after its formation (Malaysia Green Forum, 2010). NGTP focuses on six sectors such as energy, building, transportation, water and solid waste management, manufacturing and green IT (KeTTHA, 2011). Focusing on the hotel industry, energy sector concentrates on the application of green technology in power generation, energy supply, energy utilization and management programmes where else building sector focuses on adoption of green technology in the construction, management, maintenance and demolition of buildings. Green Building Index (GBI) was enacted to facilitate green grading and certification of Malaysian buildings. "GBI is a rating system providing a comprehensive framework for building assessment in terms of energy efficiency (EE), indoor environment quality, sustainable site planning and management, materials and resources, water efficiency, and innovation which is similar to the Green Star and Green Mark initiatives in Australia and Singapore" (Chua \& Oh, 2010, p. 2923). The GBI's rating system for non-residential includes the certification of factories, hospitals, offices, colleges, universities, hotels and shopping complexes (CBRE, 2010). Likewise, the water sector concentrates on green technology in utilization of water resources, solid waste management and sanitary landfill. 
Basically, NGTP covers four elements which include energy, economic, environment and social policies (KeTTHA, 2011). The economic, environmental and social policies are very consistent with the dimensions proposed by Carroll (1991) and Visser (2008). As discussed before, the government itself can be seen as a stakeholder within the community and is expected to perform its CSR. Adoption of green technology in energy usage and consumption would enhance its contribution to the national economy. These innovations and development could also enrich the country's competitiveness in the global ground. To ensure the sustainability of the country, the government describes the need to be ethical as a corporate citizen. Together, engaging in promotion and public awareness shows the consistency with the philanthropic and charitable expectation of the community. Visser (2008) has mentioned that CSR is frequently associated with philanthropy in developing countries through investments in education and other community services. For this purpose, the ministry has been working with other ministries and agencies in embracing green topics in the current Malaysian education syllabus (KeTTHA, 2011).

The government has launched a RM1.5 billion soft loan scheme which is called as the Green Technology Financing Scheme (GTFS) in year 2010 to boost the involvement of corporations and entrepreneurs into green technology. This fund offers soft loans to corporations that provide and apply green technology. For suppliers of these technologies, the maximum amount that is allocated is up to RM50 million while RM10 million is for consumer companies. Together, the government also absorbs $2 \%$ of the total interest rate charged and offers a guarantee of $60 \%$ on the amount financed while the balance of $40 \%$ by the banking institutions (KeTTHA, 2011). So far, RM805 million worth of projects benefiting some 65 companies have been sanctioned by over 20 participating banks in the country, while over RM250 million worth of loans have been disbursed (RM2.7b for Green Projects, 2012). In the latest Budget 2013, the government has announced that the GTFS fund will be increased by RM2 billion in order to boost the development and utilization of green technology and this has been extended for another three years until December 2015 (Yapp, 2012).

At the same time, the government also provides tax incentives such as tax breaks for designs and buildings that operate pleasingly with environment and tax deduction for efforts towards contribution on environmental funds (PwC, 2010). According to Bursa Malaysia Berhad (2010), one of the focus areas of sustainability is hotel in which it could utilize the supports and incentives given by the government for embracing green practices. Table 1 provides more details on tax incentives for the generation of energy from renewable sources and for energy conservation. To further illustrate, all these approaches are in line with the holistic ecosystem components emphasized by the Prime Minister which is known by the acronym AFFIRM. AFFIRM stands for Awareness, Faculty, Finance, Infrastructure, Research, Development and Commercialization and Marketing. This acronym is primarily designed to achieve commitment and contribution from all stakeholders in providing support for the protection of the environment in Malaysia (Malaysia Green Forum, 2010).

Table 1. Tax incentives for generation of energy from renewable sources and energy conservation

\begin{tabular}{|c|c|c|}
\hline \multicolumn{3}{|c|}{ Tax Incentives for Generation of Energy from Renewable Sources } \\
\hline Sector/Activity & Corporate Tax Incentives & Indirect Tax Incentives \\
\hline $\begin{array}{l}\text { Companies generating energy } \\
\text { from renewable sources }\end{array}$ & $\begin{array}{l}\text { - Pioneer status with tax exemption of } \\
100 \% \text { of statutory income for ten years; or } \\
\text { - Investment tax allowance on } \\
\text { qualifying capital expenditure incurred to } \\
\text { be set-off against } 100 \% \text { of statutory } \\
\text { income for } 5 \text { years. }\end{array}$ & $\begin{array}{l}\text { - Import duty and sales tax exemption } \\
\text { on equipment used to generate energy from } \\
\text { renewable sources not produced locally; and } \\
\text { - Sales tax exemption on equipment } \\
\text { purchased from local manufacturers. }\end{array}$ \\
\hline $\begin{array}{ll}\text { Companies } & \text { generating } \\
\text { renewable energy for own } \\
\text { consumption }\end{array}$ & $\begin{array}{l}\text { - Investment tax allowance on } \\
\text { qualifying capital expenditure incurred to } \\
\text { be set-off against } 100 \% \text { of statutory } \\
\text { income for } 5 \text { years. }\end{array}$ & \\
\hline Others & N/A & $\begin{array}{l}\text { - Import duty and sales tax exemption } \\
\text { on solar photovoltaic system equipment for } \\
\text { the use by third parties be given to importers } \\
\text { including photovoltaic service providers } \\
\text { approved by the Energy Commission; and } \\
\text { - Sales tax exemption on the purchase of } \\
\text { solar heating system equipment from local } \\
\text { manufacturers. }\end{array}$ \\
\hline
\end{tabular}






Source: PwC (2010, p. 3 \& 4).

\subsection{Green Marketing}

Green marketing was defined as "the way to conceive exchange relationships that goes beyond the current needs of the consumers, considering at the same time the social interest in protecting the natural environment" (Chamorro \& Bañegil, 2006, p. 12). Likewise, Soonthonsmai (2007) defined green marketing as actions carried out by organisations that are apprehensive about the ecology or green problems by providing the environmentally friendly goods or services to bring satisfaction among customers and the community. Referring to another definition given by Rahman, Reynolds, and Svaren (2011), green marketing means a business that is operated in a way that decreases waste, environmentally friendly, saves energy and mostly encourages environmental health and sustainability of the society.

Figure 2 is the philosophy of green marketing which differentiates traditional marketing with green marketing. It explains that green marketing is not only about understanding the commercial exchange relationship, but merely about understanding an organisation's relationship with society (Chamorro \& Bañegil, 2006) which includes the environment in general. Also stated, the effort to embrace green marketing is not only the duty of marketing department but it involves the entire organisation with different functional areas involvement such as quality, design, production and supplies. The development of green marketing evolves throughout the process of planning, implementation and control on policy of products or services, price, place (distribution) and promotion with the objectives to minimize the impact on the natural environment. 


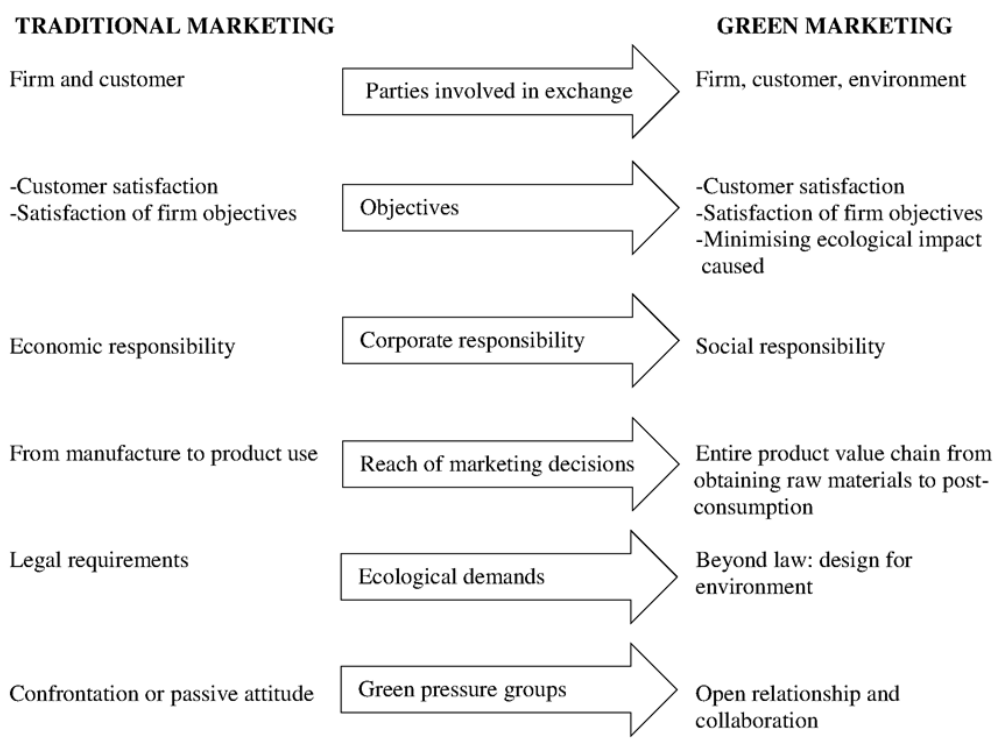

Figure 2. Differences between traditional and green marketing

Adapted from Chamorro and Bañegil (2006), p. 13

However, when discussions about green marketing and ecological degradation topics are raised, the attention is highly placed on product-based industry which includes companies that produce cars, processed food, electrical appliances, consumer goods and others. This is because they are more visible in terms of production, the usage of raw materials and output produced as the overall processes involve merely physical goods. In contrast, service organisations' efforts such as hotels may not be apparent, given the intangible nature of services (usually lack of physical presence), inseparable (produced and consumed simultaneously), heterogeneous (never exactly repeated and varies with different hands) and perishable (cannot be stored for later use) (Berry, 1980; Zeithaml, Parasuraman \& Berry, 1985). Thus, hotels are striving and finding hard times to incorporate the green practices into their daily operation while it is a challenge for them to cater the needs of green consumers with reference to sustainable practices.

\subsection{Green Marketing and the State of CSR within Hotel Industry}

As stated before, embracing green practices is known as a strategy to increase a business's CSR (Schubert, Kandampully, Solnet \& Kralj, 2010). However, knowing how these green marketing concepts and practices evolve within CSR is important. The literature on green practices of hotels has taken various ways. The primary objective of any businesses is profit maximization while trying to maintain their costs at minimum. Other independent studies have indicated that there is a positive relationship between green practices and a hotel's financial performance (Garay \& Font, 2012; Kasim, 2007; Rodríguez \& Cruz, 2007; Tarí, Claver-Cortés, Pereira-Moliner \& Molina-Azorín, 2010). According to Graci and Doods (2008), hoteliers who operate in a highly competitive market need to focus on financial savings. As hotels are spending a large amount of money for energy, water and waste disposal, the resource consumption can be reduced by 20 to 40 percent without decreasing their operational performances by switching to sustainable practices (Graci \& Doods, 2008) (e.g., source/waste reduction, product-life extension, energy/water conservation, recycling, etc.). For instance, Grand Hyatt Singapore has successfully reduced its yearly energy consumption by 8.0 million kWh by adopting the Green Energy Management project with an annual savings of more than $\$ 1$ million on utility bills (National Climate Change Committee, 2002). Even though other hotels may not show the same savings potential, but Grand Hyatt has verified the possibilities to achieve it where other hotels can set it as one of their goals (Xuchao, Priyadarsini \& Eang, 2010).

At the same time, green management in the hotel industry is now playing a critical role in marketing management (Han, Hsu, Lee \& Sheu, 2011). Stated by Ottman (1992), environmental concepts and considerations should be incorporated into all areas of marketing if companies want to implement green marketing effectively. It is now becoming very apparent that greening the hotel's operation makes economic 
sense beyond being the right thing to do. Economic responsibility of a hotel often measured quantitatively using its financial performance and cost savings. However, this green marketing has all the abilities to increase the economic sense of a hotel unnoticeably by improving its brand image as green. Besides being a visual recognition, a brand also relates to a consumer's intuitive feeling about a service or a product. It is also known as the sum of all consumer experiences and touch points. At this point, the hoteliers need a brand that creates an image that is relevant to the customer's needs and values. Consequently, a green brand image can help a hotel to enhance its appearance as an eco-friendly organisation and strengthen its CSR in the process of attracting the public towards positive purchasing decisions. As the hotels are recognised with an ecological image, very often they will also be associated as an organisation which emphasises its CSR. This explains that green marketing, green brand image and CSR are interrelated to one another. By the same token, brands established on genuine CSR identity are more likely to change resistant consumers and invite loyal ones (Pérez, 2009). At this moment, the hotels are marketable and hence, they indirectly increase the economic performances of their companies.

On the other hand, Brammer et al. (2012) have said that it is relatively unfit to engage in CSR as one of the ways to increase a firm's performance. This has been supported by Matten and Moon (2008) who stated that many successful corporations in Japan and Western Europe still give high attention to CSR and related concepts, and profit maximization is not their main purpose of CSR. This indicates that there is something beyond the economic responsibilities in which the attitude and behaviour to be ethically and socially responsible are the reasons to engage in CSR. This is in line with Carroll (1991) and Visser (2008) about ethical responsibilities. A hotel can portray its ethical responsibilities throughout its site selection, construction of the hotel and also design in which environmental criteria can be adopted to minimize the impact. At the same time, environmental management practices such as passive space conditioning, improved insulation, lighting technologies and water conservation techniques can also be implemented. Other simple practices include reducing the amount of consumer-generated waste through implementation of refillable shampoo dispensers, recycling bins in rooms and encouraging reuse of linens and towels (Millar \& Baloglu, 2011). An exceptional model of this is the Crestwood Corporate Centre Building No. 8 in Richmond, British Columbia, Canada in which the building was designed to meet the environmental necessities set by the Advanced Buildings Program and operates currently at less than 50 percent of the annual energy use of an American Society of Heating, Refrigerating and Air-Conditioning Engineers (ASHRAE) reference building (Bohdanowicz, Churie-Kallhauge \& Martinac, 2001).

Attention is also highly given to the challenges that drive or obstruct the adoption of environmentally friendly behaviour among hotels (Leonidou et al., 2013). Regulatory measures seemed to be a reason for firms to hold onto green marketing while this is also seen as one of the dimensions of CSR (Carroll, 1991). When the hotels' policies are in line with the legal standard, they will be in a privileged position as investing in new technologies to comply with the legal requirements is not needed (Fernández-Allies \& Cuadrado-Marqués, 2012). Studies have also indicated that the factors that obstruct hoteliers from adopting the green technologies are lack of infrastructural support by local authorities and additional costs involved in proceeding with ecological actions (Chan, 2008; Tzschentke, Kirk \& Lynch, 2008). However, many organisations are less informed about the support provided by the governments. Governments in different countries form laws and are also providing subsidies to motivate hotels to support sustainability (Chan \& Wong, 2006) in which Malaysia is one of them.

CSR is also known as an important societal issue to stakeholder theory (Flak \& Rose, 2005). Carroll (1991, p. 43) has mentioned that "there is a natural fit between the idea of corporate social responsibility and an organisation's stakeholders". This theory actually describes that green practices give hotels a competitive advantage. When the green strategies are implemented effectively, it may change the image and the perspectives of the operations from the point of view of stakeholders, customers, employees and other groups (Ham \& Choi, 2012). This theory also explains that organisations are expected to manage responsibly and offer a duty of care towards the stakeholders' interests and local communities (Simmons, 2004). Understanding that customers are also one of the stakeholders, knowing what they prefer and not could actually provide some insights towards the overall performance of the hotels.

\subsection{Challenges for Green Marketing}

It has been reported that customers show positive intention to visit hotels that adopt green practices than preferring hotels that do not employ them (Ham \& Choi, 2012). Whilst tourists and businesses recommence travel, many discerning clients will begin looking for differentiation that is related to sustainability practices (Bursa Malaysia Berhad, 2010). According to Mensah (2004), a study done by the International Hotels Environment Initiative (IHEI) and Accor has indicated that $90 \%$ of tourists like to stay in hotels which give attention to the environment. However, when the customers find the green claims are fake or forged, the trust towards the organisation get affected (Bhaskaran, Polonsky, Cary \& Fernandez, 2006). These types of claims are 
called "greenwashing" (Sinnappan \& Rahman, 2011). This is one of the greatest challenges that hoteliers are facing in which they have to avoid if they want to cater the green segments. Peattie and Crane (2005) have listed five marketing tactics that may lead to the failure of green marketing and they are:

1) Green Selling. Green statements are being added to the existing products with the objective to just increase sales. This is believed to be a good marketing strategy for companies to boost their revenue.

2) Green Spinning. Use public relation as a promotional tool to reject the critics made by the society regarding the organisation's practice or performance. This is because public relation communicates the message effectively to the news media and eventually to the public. The resulting publicity is basically quick due to the influence represented by the media.

3) Green Harvesting. Green marketing approaches are only used when they lead to cost savings in operation or production.

4) Entrepreneur Marketing. Products that are produced with green claims do not match with the expectation of customers. This is due to not knowing and studying the real needs and wants of consumers.

5) Compliance Marketing. Comply with the regulations by taking simple actions without any intentions to go beyond the stated legislations. This strategy is employed as a way to avoid penalties from the government.

So far, many countries have established their own eco-certification scheme (Shieh, 2012). This scheme has a primary motive of driving a revolution towards more sustainable practices and lessening ecological impacts by the hotel industry. It forms concise guidelines for best sustainable practices and awards the label of eco-friendly to hotels that are able to meet the requirements. This at the same time helps the public to distinguish between the real green hotels and hotels that are practicing greenwashing. In the same vein, green brand image is developed and it strengthens the marketing efforts of hotels. According to Bastič and Gojčič (2012), the certification of eco-friendly plays an important role in the process of decision making by tourists. This seemed to be a reliable source for tourists to choose for environmentally friendly service quality. An eco-friendly label also easily attracts tourists who are highly concerned about the environment and willing to pay premium price for the service consumption. This eco-certification scheme basically looks into all areas of environmental practices such as energy, water, waste management as well as public and community outreach. Hotels that attain certification recognise themselves as front-runners in practicing green standards, energy conservation and achieving a sustainable future. At the same time, earning this certification is found to be significant, not only for the well-being of the surroundings but also for the hotel's bottom line. Table 2 provides some examples of eco-certification scheme recognised by different countries around the world. Each certification audit looks at its own sustainable hotel operation standards which are vigorous, comprehensive, accredited and continuously inspected to ensure the superiority of the label is maintained.

Table 2. Eco-certification schemes

\begin{tabular}{ll}
\hline Location/Country & Eco-certification scheme \\
\hline North America & Green Leaf \\
Canada & Green Key \\
Britain & Green Tourism Business Scheme \\
United States & Green Seal \\
EU & Ecolabel and Green Key \\
China & Green Hotel Standard \\
Taiwan & Green Mark \\
Singapore & SEC Eco Hotel Label \\
\hline
\end{tabular}

\section{Recommendation}

Today, successful businesses integrate their creatively innovated strategy and performance as a form of CSR into their corporate culture. While hotels are increasingly defining a sustainable green business model to fit the request of the community, it may be gradually introduced into their corporate culture. As known, corporate culture describes and governs the ways a company's owners and employees think, feel and act. By this, 
realisation towards sustainability may only be achieved when it is driven internally. Behavioural change, awareness, conviction, knowledge and attitude to support the "Go Green" concept among the key stakeholders require a continuous enforcement which can be obtained from the corporate values. These values need to be incorporated and reflected in all processes within the hotel's core operation and will serve as a guidepost to direct the management and its team.

In addition, certifications given to hotels are evidence that a third party has independently verified adherence to several published requirements. These certifications vary widely in their scope and stringency, and mostly highlight various requirements of environmental practices. Indeed, standards and certifications are the key to recognition and validation, but they are just one green marketing tool which notifies the public that the hotels have included various green practices into their operations. Basically, such certifications given to hotels may become a tool for attracting consumers who are looking for ways to reduce adverse environmental impacts through their purchasing and consumption choices. However, it can be challenging to determine how the practices can be effectively communicated and delivered to the customers. In this sense, the hotels must develop an effective marketing program by using appropriate tools to reach consumers. At this point of view, a combination of seven tools, often called the seven Ps (product, price, place, promotion, people, physical evidence and process) or extended marketing mix may be one of the best choices to provide a cohesive marketing program. Due to the nature that services are intangible, perishable, inseparable and heterogeneous (Berry, 1980; Zeithaml, Parasuraman \& Berry, 1985), applying the seven Ps instead of the traditional four Ps (product, price, place and promotion) (Magrath, 1986) may help companies such as hotels to develop better environmentally friendly strategies for superior service delivery for their customers.

\section{Conclusion}

CSR is a part of corporate activity that lies between business and community. The need to behave in a socially responsible way has received the society's high attention (Coles, Fenclova \& Dinan, 2011). This concept will always be an important part of business language and operations while it has been supported by many theories and continually consistent with the expectations of the society. It also addresses and captures the most vital concerns of the community related to business and society relations (Carroll, 1999). When this approach is given serious consideration either voluntarily or due to legal requirements, it provides a unique competitive advantage. Additionally, such advantages will give greater benefits to hotels that are operating in a highly competitive environment because it helps to differentiate from other lodging service providers.

Furthermore, green based practices will be an added advantage for hotels to achieve superior financial and market performance in ensuring a balance between development and environmental sustainability. The reason behind this is mainly due to the high pressure and concern given to green marketing issues in which it has become increasingly evident in both academic and real industries. At the same time, just by claiming that the hoteliers have initiated CSR by embracing green practices is not sufficient. Their initiatives need to be clearly demonstrated to the public to avoid greenwashing. Together, they must understand that they have to spend a sufficient amount of time in embarking on promotional and communication efforts and educating the public to reach the full support of the community, media groups and societal groups.

\section{Suggestions for Future Research}

As there are myriad of green initiatives within the industry, future research may focus on green practices that can be employed by hotels which provides greater insights to the literature of hospitality and sustainable development. CSR is an important societal issue to stakeholder theory and it is found that it improves employees' morale, loyalty, retention rates and satisfaction (Flak \& Rose, 2005). Thus, studying the commitment level of hotel employees to conserve the environment and how they perceive the hotel's CSR initiatives are crucial. As suppliers are also one of the stakeholders, understanding how hotels team up with them to exert green marketing within the value chain would also be another direction for future research. Other than that, the number of budget hotels in the country is rising meaningfully from time to time parallel with the progress of the tourism sector. The demand for budget hotels has been extraordinarily increasing as tourists generally control their budget for accommodation. However, high-ranked hotels and budget hotels may have different approaches towards green practices due to financial constraints. Studying both segments separately could also add more benefits to the literature.

\section{References}

Ali, H. (2011, April 21). Malaysia can Achieve High Growth Again. New Straits Times. Retrieved from http://www.accessmylibrary.com/article-1G1-254549381/malaysia-can-achieve-high.html 
Alniacik, U., Alniacik, E., \& Genc, N. (2011). How corporate social responsibility information influences stakeholders' intentions. Corporate Social Responsibility and Environmental Management, 18(4), 234-245. http://dx.doi.org/10.1002/csr.245

Baron, D. P. (2001). Private politics, corporate social responsibility, and integrated strategy. Journal of Economics \& Management Strategy, 10(1), 7-45. http://dx.doi.org/10.1162/105864001300122548

Bastič, M., \& Gojčič, S. (2012). Measurement scale for eco-component of hotel service quality. International Journal of Hospitality Management, 31(3), 1012-1020. http://dx.doi.org/10.1016/j.ijhm.2011.12.007

Berry, L. L. (1980). Services marketing is different. Business, 30(3), 24-29.

Bhaskaran, S., Polonsky, M., Cary, J., \& Fernandez, S. (2006). Environmentally sustainable food production and marketing: opportunity or hype? British Food Journal, 108(8), 677-690. http://dx.doi.org/10.1108/00070700610682355

Bohdanowicz, P. (2006). Environmental awareness and initiatives in the Swedish and Polish hotel industries-survey results. International Journal of Hospitality Management, 25(4), 662-682. http://dx.doi.org/10.1016/j.ijhm.2005.06.006

Bohdanowicz, P., Churie-Kallhauge, A., \& Martinac, I. (2001). Energy-efficiency and conservation in hotels-towards sustainable tourism. $4^{\circ}$ Simpósio Internacional em Arquitetura da Ásia e Pacífico, Havaí.

Bondy, K., Moon, J., \& Matten, D. (2012). An institution of corporate social responsibility (CSR) in multi-national corporations (MNCs): Form and implications. Journal of Business Ethics, 1-19.

Brammer, S., Jackson, G., \& Matten, D. (2012). Corporate Social Responsibility and institutional theory: new perspectives on private governance. Socio-Economic Review, 10(1), 3-28. http://dx.doi.org/10.1093/ser/mwr030

Bursa Malaysia Berhad. (2010). Hotels. $\quad$ Retrieved from http://ablemen.com/sustainability/lock/focus_hotels.php?index $=9$

Carroll, A. B. (1979). A three-dimensional conceptual model of corporate performance. Academy of management review, 497-505.

Carroll, A. B. (1991). The pyramid of corporate social responsibility: toward the moral management of $\begin{array}{lllll}\text { organizational } & \text { stakeholders. } & \text { Business } & \text { horizons, } & 34(4),\end{array}$ http://dx.doi.org/10.1016/0007-6813(91)90005-G

Carroll, A. B. (1999). Corporate social responsibility evolution of a definitional construct. Business \& society, 38(3), 268-295. http://dx.doi.org/10.1177/000765039903800303

Carroll, A. B., \& Shabana, K. M. (2010). The business case for corporate social responsibility: a review of concepts, research and practice. International Journal of Management Reviews, 12(1), 85-105. http://dx.doi.org/10.1111/j.1468-2370.2009.00275.x

CBRE. (2010). Going Green Malaysia. Retrieved from http://www.cbre.com.my/uploads/CBRE-Special-Report-Going-Green-Malaysia.pdf

Chamorro, A., \& Bañegil, T. M. (2006). Green marketing philosophy: a study of Spanish firms with ecolabels. Corporate Social Responsibility and Environmental Management, 13(1), 11-24. http://dx.doi.org/10.1002/csr.83

Chan, E. S. (2008). Barriers to EMS in the hotel industry. International Journal of Hospitality Management, 27(2), 187-196. http://dx.doi.org/10.1016/j.jhm.2007.07.011

Chan, E. S., \& Wong, S. C. (2006). Motivations for ISO 14001 in the hotel industry. Tourism Management, 27(3), 481-492. http://dx.doi.org/10.1016/j.tourman.2004.10.007

Chen, Y. S., \& Chang, C. H. (2012). Enhance green purchase intentions: The roles of green perceived value, green perceived risk, and green trust. Management Decision, 50(3), 502-520. http://dx.doi.org/10.1108/00251741211216250

Chua, S. C., \& Oh, T. H. (2010). Review on Malaysia's national energy developments: Key policies, agencies, programmes and international involvements. Renewable and Sustainable Energy Reviews, 14(9), 2916-2925. http://dx.doi.org/10.1016/j.rser.2010.07.031

Coles, T., Fenclova, E., \& Dinan, C. (2011). Responsibilities, recession and the tourism sector: perspectives on CSR among low-fares airlines during the economic downturn in the UK. Current Issues in Tourism, 14(6), 
519-536. http://dx.doi.org/10.1080/13683500.2010.544719

Colley, J., Doyle, J., Logan, G., \& Stettinius, W. (2003). Corporate Governance. New York: McGraw-Hill.

Cowper-Smith, A., \& de Grosbois, D. (2011). The adoption of corporate social responsibility practices in the $\begin{array}{lllll}\text { airline industry. Journal of Sustainable Tourism, } & 19(1), & \text { 59-77. }\end{array}$ http://dx.doi.org/10.1080/09669582.2010.498918

Dahlsrud, A. (2008). How corporate social responsibility is defined: an analysis of 37 definitions. Corporate social responsibility and environmental management, 15(1), 1-13. http://dx.doi.org/10.1002/csr.132

Detomasi, D. A. (2008). The political roots of corporate social responsibility. Journal of Business Ethics, 82(4), 807-819. http://dx.doi.org/10.1007/s10551-007-9594-y

Fernández-Alles, M., \& Cuadrado-Marqués, R. (2012). Hotel Environmental Impact Management: A Case Study in Cádiz Province. Soft Computing in Management and Business Economics, 335-346.

Flak, L. S., \& Rose, J. (2005). Stakeholder governance: Adapting stakeholder theory to e-government. Communications of the Association for Information Systems, 16(1), 31.

Fougère, M., \& Solitander, N. (2009). Against corporate responsibility: critical reflections on thinking, practice, content and consequences. Corporate Social Responsibility and Environmental Management, 16(4), 217-227. http://dx.doi.org/10.1002/csr.204

Garay, L., \& Font, X. (2012). Doing good to do well? Corporate social responsibility reasons, practices and impacts in small and medium accommodation enterprises. International Journal of Hospitality Management, 31(2), 329-337. http://dx.doi.org/10.1016/j.ijhm.2011.04.013

Garriga, E., \& Melé, D. (2004). Corporate social responsibility theories: mapping the territory. Journal of Business Ethics, 53(1), 51-71. http://dx.doi.org/10.1023/B:BUSI.0000039399.90587.34

Googins, B. K., Mirvis, P. H., \& Rochlin, S. A. (2007). Beyond good company: Next generation corporate citizenship. Palgrave Macmillan. http://dx.doi.org/10.1057/9780230609983

Graci, S., \& Dodds, R. (2008). Why go green? The business case for environmental commitment in the Canadian hotel industry. Anatolia, 19(2), 251-270. http://dx.doi.org/10.1080/13032917.2008.9687072

Griffin, J. J., \& Prakash, A. (2010). Corporate Responsibility Initiatives and Mechanisms. Business \& Society, 49(1), 179-184. http://dx.doi.org/10.1177/0007650309352231

Ham, S., \& Choi, Y. K. (2012). Effect of cause-related marketing for green practices in the hotel industry. Journal of Global Scholars of Marketing Science, 22(3), 249-259. http://dx.doi.org/10.1080/21639159.2012.696338

Hamid, M. A., Ismail, N., Fuza, Z. I. M., Ahmad, K. N., \& Awang, K. W. (2012). Sustainable tourism development practices of MICE venue provider in East Coast Region, Peninsula Malaysia. Hospitality and Tourism, 87.

Han, H., Hsu, L. T. J., Lee, J. S., \& Sheu, C. (2011). Are lodging customers ready to go green? An examination of attitudes, demographics, and eco-friendly intentions. International Journal of Hospitality Management, 30(2), 345-355. http://dx.doi.org/10.1016/j.ijhm.2010.07.008

Hemdi, M. A., Razali, M. A., Rashid, N. N. A., \& Nordin, R. (2012). Organizational citizenship behavior of hotel employees: Investigating the impact of organizational justice. Hospitality and Tourism, 159.

Holcomb, J. L., Upchurch, R. S., \& Okumus, F. (2007). Corporate social responsibility: what are top hotel companies reporting? International Journal of Contemporary Hospitality Management, 19(6), 461-475. http://dx.doi.org/10.1108/09596110710775129

Hsieh, N. H. (2009). Corporate social responsibility and the priority of shareholders. Journal of Business Ethics, 88, 553-560. http://dx.doi.org/10.1007/s10551-009-0314-7

Hsieh, Y. C. J. (2012). Hotel companies' environmental policies and practices: a content analysis of their web pages. International Journal of Contemporary Hospitality Management, 24(1), 97-121. http://dx.doi.org/10.1108/095961112

Ismail, M. (2009). Corporate social responsibility and its role in community development: An international perspective. The Journal of International Social Research, 2(9), 200-209.

Jamali, D. (2008). A stakeholder approach to corporate social responsibility: a fresh perspective into theory and 
practice. Journal of Business Ethics, 82(1), 213-231. http://dx.doi.org/10.1007/s10551-007-9572-4

Jamali, D., \& Mirshak, R. (2007). Corporate social responsibility (CSR): theory and practice in a developing country context. Journal of Business Ethics, 72(3), 243-262. http://dx.doi.org/10.1007/s10551-006-9168-4

Jhawar, A., Kohli, G., Li, J., Modiri, N., Mota, V., Nagy, R., \& Shum, C. (2012). Eco-Certification Programs for Hotels in California: Determining Consumer Preferences for Green Hotels.

Kasim, A. (2007). Corporate environmentalism in the hotel sector: evidence of drivers and barriers in Penang, Malaysia. Journal of Sustainable Tourism, 15(6), 680-699. http://dx.doi.org/10.2167/jost575.0

KeTTHA. (2011). Going Green: Morally Sustainable \& Financially Viable. Retrieved from http://www.kettha.gov.my/en/content/going-green-morally-sustainable-financially-viable

Larsen, G., \& Lawson, R. (2012). Consumer Rights: A Co-optation of the Contemporary Consumer Movement. Journal of Historical Research in Marketing, 5(1), 6-6.

Lee, M. D. P. (2008). A review of the theories of corporate social responsibility: Its evolutionary path and the road ahead. International Journal of Management Reviews, 10(1), 53-73. http://dx.doi.org/10.1111/j.1468-2370.2007.00226.x

Leonidou, L. C., Leonidou, C. N., Fotiadis, T. A., \& Zeriti, A. (2013). Resources and capabilities as drivers of hotel environmental marketing strategy: Implications for competitive advantage and performance. Tourism Management, 35, 94-110. http://dx.doi.org/10.1016/j.tourman.2012.06.003

Lu, J. Y., \& Castka, P. (2009). Corporate social responsibility in Malaysia-experts' views and perspectives. Corporate Social Responsibility and Environmental Management, 16(3), 146-154. http://dx.doi.org/10.1002/csr.184

Lundberg, C., Fredman, P., \& Wall-Reinius, S. (2012). Going for the green? The role of money among nature-based tourism entrepreneurs. Current Issues in Tourism, 1-8. http://dx.doi.org/10.1080/13683500.2012.746292

Magrath, A. J. (1986). When marketing services, 4 Ps are not enough. Business Horizons, 29(3), 44-50. http://dx.doi.org/10.1016/0007-6813(86)90007-8

Mahmood, M., \& Humphrey, J. (2013). Stakeholder Expectation of Corporate Social Responsibility Practices: A Study on Local and Multinational Corporations in Kazakhstan. Corporate Social Responsibility and Environmental Management, 20, 168-181. http://dx.doi.org/10.1002/csr.1283

Malaysia Green $\quad$ Forum. (2010). NGTP. $\quad$ Retrieved from $\mathrm{http} / / / \mathrm{www} .1 \mathrm{malaysia.com} . \mathrm{my} / \mathrm{bm} / \mathrm{speeches} / \mathrm{sri}$-siantan-conference-hall-putrajaya

Matten, D., \& Moon, J. (2008). "Implicit" and "explicit" CSR: a conceptual framework for a comparative understanding of corporate social responsibility. Academy of Management Review, 33(2), 404-424. http://dx.doi.org/10.5465/AMR.2008.31193458

Mensah, I. (2004). Environmental management practices in US Hotels. Retrieved from http://www.hotelonline.com/News/PR20042nd/May04EnvironmentalPractices.html

Millar, M., \& Baloglu, S. (2011). Hotel Guests' Preferences for Green Guest Room Attributes*. Cornell Hospitality Quarterly, 52(3), 302-311. http://dx.doi.org/10.1177/1938965511409031

Ministry of Tourism Malaysia. (2012). ETP: Transforming Tourism to the New Heights. Retrieved from http://www.motour.gov.my/en/media/press-release/465-etp-usaha-mentransfromasi-pelancongan-ke-tahap-b aru.html

Mullerat, R., \& Brennan, D. (2005). Corporate social responsibility: The corporate governance of the 21st century. Kluwer Law International.

Myung, E., McClaren, A., \& Li, L. (2012). Environmentally related research in scholarly hospitality journals: Current status and future opportunities. International Journal of Hospitality Management, 31(4), 1264-1275. http://dx.doi.org/10.1016/j.ijhm.2012.03.006

National Climate Change Committee. (2002). Green energy management (GEM) at Grand Hyatt Singapore. Retrieved from http://www.nccc.gov.sg/building/GEM.pdfS

Nicholls, S., \& Kang, S. (2012). Going green: the adoption of environmental initiatives in Michigan's lodging sector. Journal of Sustainable Tourism, 20(7), 953-974. http://dx.doi.org/10.1080/09669582.2011.645577 
Okpara, J. O., \& Wynn, P. M. (2012). Stakeholders' perceptions about corporate social responsibility: Implications for poverty alleviation. Thunderbird International Business Review, 54(1), 91-103. http://dx.doi.org/10.1002/tie.21441

Ottman, J. (1992). Green marketing: responding to environmental consumerism. NTC Business Books

Peattie, K., \& Crane, A. (2005). Green marketing: legend, myth, farce or prophesy? Qualitative Market Research: An International Journal, 8(4), 357-370. http://dx.doi.org/10.1108/13522750510619733

Pérez, R. C. (2009). Effects of perceived identity based on corporate social responsibility: the role of consumer identification with the company. Corporate Reputation Review, 12(2), 177-191. http://dx.doi.org/10.1057/crr.2009.12

PwC. (2010). Green Tax Incentives for a Sustainable Malaysia. (Alert Issue No. 86) Retrieved from http://www.pwc.com/my/en/forms/pwc-alert-issue-86.jhtml

Rahman, I., Reynolds, D., \& Svaren, S. (2011). How "green" are North American hotels? An exploration of low-cost adoption practices. International Journal of Hospitality Management, 31(3), 720-727. http://dx.doi.org/10.1016/j.ijhm.2011.09.008

RM2.7b for green projects. (2012, October 3). The Star Online. Retrieved from $\mathrm{http}: / /$ thestar.com.my/news/story.asp?file $=/ 2012 / 10 / 3 /$ budget $/ 12115809 \& \mathrm{sec}=$ budget

Robinot, E., \& Giannelloni, J. L. (2010). Do hotels'“green" attributes contribute to customer satisfaction? Journal of Services Marketing, 24(2), 157-169. http://dx.doi.org/10.1108/08876041011031127

Rodríguez, F. J. G., \& Cruz, Y. (2007). Relation between social-environmental responsibility and performance in hotel firms. International Journal of Hospitality Management, 26(4), 824-839. http://dx.doi.org/10.1016/j.ijhm.2006.08.003

Saadatian, O., Haw, L. C., Mat, S. B., \& Sopian, K. (2012). Perspective of Sustainable Development in Malaysia. International Journal of Energy and Environment, 2(6), 260-267.

Schmidheiny, S. (2006). A view of corporate citizenship in Latin America. Journal of Corporate Citizenship, 21(1), 21-24.

Schubert, F., Kandampully, J., Solnet, D., \& Kralj, A. (2010). Exploring consumer perceptions of green restaurants in the US. Tourism and Hospitality Research, 10(4), 286-300. http://dx.doi.org/10.1057/thr.2010.17

Secchi, D. (2007). Utilitarian, managerial and relational theories of corporate social responsibility. International Journal of Management Reviews, 9(4), 347-373. http://dx.doi.org/10.1111/j.1468-2370.2007.00215.x

Shafaat, M. F., \& Sultan, A. (2012). Green marketing. EXCEL International Journal of Multidisciplinary Management Studies, 2(5), 184-195.

Shieh, H. S. (2012). The greener, the more cost efficient? An empirical study of international tourist hotels in Taiwan. International Journal of Sustainable Development \& World Ecology, 19(6), 536-545. http://dx.doi.org/10.1080/13504509.2012.741627

Shum, P. K., \& Yam, S. L. (2011). Ethics and law: Guiding the invisible hand to correct corporate social responsibility externalities. Journal of business ethics, 98(4), 549-571. http://dx.doi.org/10.1007/s10551-010-0608-9

Simmons, J. (2004). Managing in the post-managerialist era: Towards socially responsible corporate governance. Management Decision, 42(3/4), 601-611. http://dx.doi.org/10.1108/00251740410518985

Singapore Environment Council. (2012). Green Label Hotel Certification. Retrieved from http://www.greenlabel.sg/about/green_label_hotel_certification

Singh, P. B., \& Pandey, K. K. (2012). Green marketing: Policies and practices for sustainable development. Integral Review, 5(1), 22-30.

Sinnappan, P., \& Rahman, A. A. (2011). Antecedents of Green Purchasing Behavior among Malaysian $\begin{array}{llll}\text { Consumers. International } & \text { Business }\end{array}$ http://dx.doi.org/10.3923/ibm.2011.129.139

Smerecnik, K. R., \& Andersen, P. A. (2011). The diffusion of environmental sustainability innovations in North American hotels and ski resorts. Journal of Sustainable Tourism, 19(2), 171-196. http://dx.doi.org/10.1080/09669582.2010.517316 
Smith, E. E., \& Perks, S. (2012). A perceptual study of the impact of green practice implementation on the business functions. Southern African Business Review, 14(3).

Soonthonsmai, V. (2007). Environmental or green marketing as global competitive edge: Concept, synthesis, and implication. In EABR (Business) and ETLC (Teaching) Conference Proceeding, Venice, Italy.

Sotorrío, L. L., \& Sánchez, J. L. F. (2010). Corporate social reporting for different audiences: The case of multinational corporations in Spain. Corporate Social Responsibility and Environmental Management, 17(5), 272-283. http://dx.doi.org/10.1002/csr.215

Sundaram, A. K., \& Inkpen, A. C. (2004). The corporate objective revisited. Organization Science, 15(3), 350-363. http://dx.doi.org/10.1287/orsc. 1040.0068

Tarí, J. J., Claver-Cortés, E., Pereira-Moliner, J., \& Molina-Azorín, J. F. (2010). Levels of quality and environmental management in the hotel industry: Their joint influence on firm performance. International Journal of Hospitality Management, 29(3), 500-510. http://dx.doi.org/10.1016/j.ijhm.2009.10.029

Teng, C. C., Horng, J. S., Hu, M. L. M., Chien, L. H., \& Shen, Y. C. (2012). Developing energy conservation and carbon reduction indicators for the hotel industry in Taiwan. International Journal of Hospitality Management, 31(1), 199-208. http://dx.doi.org/10.1016/j.ijhm.2011.06.006

Tsoi, J. (2010). Stakeholders' perceptions and future scenarios to improve corporate social responsibility in Hong Kong and mainland China. Journal of business ethics, 91(3), 391-404. http://dx.doi.org/10.1007/s10551-009-0091-3

Tzschentke, N. A., Kirk, D., \& Lynch, P. A. (2008). Going green: Decisional factors in small hospitality operations. International Journal of Hospitality Management, 27(1), 126-133. http://dx.doi.org/10.1016/j.ijhm.2007.07.010

Visser, W. (2008). Corporate social responsibility in developing countries. The Oxford handbook of corporate social responsibility, 473-479.

Wood, D. J. (2010). Measuring corporate social performance: a review. International Journal of Management Reviews, 12(1), 50-84. http://dx.doi.org/10.1111/j.1468-2370.2009.00274.x

Xuchao, W., Priyadarsini, R., \& Eang, L. S. (2010). Benchmarking energy use and greenhouse gas emissions in Singapore's hotel industry. Energy Policy, 38(8), 4520-4527. http://dx.doi.org/10.1016/j.enpol.2010.04.006

Yapp, E. (2012, October 2). Industry generally upbeat about Budget 2013. Digital News Asia. Retrieved from http://www.digitalnewsasia.com/digital-economy/industry-generally-upbeat-about-budget2013

Zainordin, N. B., Abdullah, S. M. B., \& Baharum, Z. B. A. (2012). Light and Space: Users Perception towards Energy Efficient Buildings. Procedia-Social and Behavioral Sciences, 36, 51-60. http://dx.doi.org/10.1016/j.sbspro.2012.03.006

Zeithaml, V. A., Parasuraman, A., \& Berry, L. L. (1985). Problems and strategies in services marketing. The Journal of Marketing, 33-46. http://dx.doi.org/10.2307/1251563

\section{Copyrights}

Copyright for this article is retained by the author(s), with first publication rights granted to the journal.

This is an open-access article distributed under the terms and conditions of the Creative Commons Attribution license (http://creativecommons.org/licenses/by/3.0/). 